\title{
A twilight for the complete nitrogen removal via synergistic partial-denitrification, anammox, and DNRA process
}

\author{
Hafiz Adeel Ahmad ${ }^{1,2,7}$, Beibei Guo ${ }^{1,2,7}$, Xuming Zhuang ${ }^{3}$, Yiyi Zhao ${ }^{2}$, Shakeel Ahmad ${ }^{4}$, Taeho Lee ${ }^{5}$, Jiegao Zhu ${ }^{6}$,
} Yuliang Dong iD $^{1 凶}$ and Shou-Qing $\mathrm{Ni}\left(\mathrm{iD}^{1,2 凶}\right.$

The prolonged start-up time and low total nitrogen removal of anammox hinder its full-scale application. Herein, application of nano-zerovalent iron and low strength magnetic field in sole and in combination to abbreviate the start-up period and long-term process stability of anammox was carried out. The reactor's anammox start-up with the only magnetic field (R3) was 34 days, saving 43.3\% time compared with the control. The increase of nitrogen removal efficiency over the control was $43.7 \%$ during the start-up period. However, the reactor with the coupled treatment of nano-zerovalent iron and magnetic field (R4) was more stable with higher nitrogen removal efficiency $(80 \%)$ at high nitrogen loading $\left(5.28 \mathrm{~kg} / \mathrm{m}^{3} / \mathrm{d}\right)$. Anammox gene copy number in R4 was highest after 180 days of culture, followed by nano-zerovalent iron (R2) and R3 reactor. The functional genes of denitrifying bacteria (nirk and nirS) were also identified in all reactors with higher copy numbers in R2, followed by R4 and R3. Furthermore, high throughput analysis showed that the Thauera performing partial denitrification, Ignavibacterium performing dissimilatory nitrate reduction to ammonium or nitrite were also present in all reactors, more abundant in R4, confirming that the higher nitrogen removal efficiency in R4 was attributed to the synergistic relationship of other nitrogenous genera with anammox. The higher abundance of PD and DNRA in the reactor with the coupled treatment of nano-zero valent iron and magnetic field, achieved in this research, opens the opportunity of complete nitrogen removal via synergistic partial-denitrification, anammox, and DNRA (SPDAD) process.

npj Clean Water (2021)4:31; https://doi.org/10.1038/s41545-021-00122-5

\section{INTRODUCTION}

Anaerobic ammonium oxidation (anammox) is an efficient and economically feasible microbial process for removing nitrogen from wastewater ${ }^{1,2}$. Anammox was first described by Mulder and his colleagues in $1995^{3}$. Nowadays, anammox has become popular among environmental engineers due to its great potential for nitrogen removal from wastewater without consuming oxygen and organic carbon. Till now, more than 114 full-scale wastewater treatment plants based on anammox have been established worldwide ${ }^{4}$. The main challenges in the anammox process's commercialization are its longer start-up period due to slow growth rate and process stability under changing nitrogen loads. The anammox took more than 3 years to realize the process performance at a full-scale treatment plant ${ }^{5}$. The realized nitrogen removal was $7.1 \mathrm{~kg} \mathrm{~N} / \mathrm{m}^{3} / \mathrm{d}$ in the first full-scale treatment plant ${ }^{5}$, comparable with conventional nitrification and denitrification. After start-up, the anammox process is not stable, mainly when high nitrogen loading is applied ${ }^{6-8}$. The variations of nitrogen loading rate can considerably affect the nitrogen removal rate ${ }^{9}$. The increment in the nitrogen loading rate decreased nitrogen removal efficiency from above $83 \%$ to below $43 \%{ }^{6}$. Therefore, researchers are in a continuous struggle to devise strategies to reduce anammox start-up time and long-term process stability under changing nitrogen load. The low total nitrogen removal efficiency ( $88 \%$ maximum theoretically) is another complication at the large-scale anammox application.
The use of pre-enriched anammox culture from anaerobic granular sludge-activated sludge and sediments from different environments have been documented as one of the potential approaches employed at full-scale to reduce the start-up time of the anammox process ${ }^{10,11}$. Pre-enrichment of anammox was achieved with different pre- and post-treatment. The anammox start-up time was reduced by $12.5 \%$ with autoclavation of anaerobic granular sludge ${ }^{12}$ and $26.9 \%$ with the addition of reduced graphene ${ }^{13}$. Furthermore, anammox process stability highly relies on the retention of biomass in the reactors. Previous studies revealed that the anammox process shows good resistance to the substrate shocks in various reactor configurations $s^{6,10,14}$. Moreover, a synergistic relationship between different nitrogenous genera may help anammox to resist against high loading of the substrate. Previously, it has been observed that overgrowth of other nitrogen-related bacteria such as DNRA in the anammox reactor destroys the anammox performance ${ }^{15}$. Simultaneously, partial denitrifying bacteria, denitrifying anaerobic methane-oxidizing bacteria, and DNRA may support the anammox process and increase the nitrogen removal efficiency ${ }^{6,16-18}$.

Nano-scale zero-valent iron ( $\mathrm{nZVI})$ is a widely used nanomaterial for remediating soil and groundwater ${ }^{19,20}$. Anammox activity was devitalized when exposed to $100 \mathrm{mg} / \mathrm{L} \mathrm{nZVI}{ }^{21}$, while no influence on anammox activity was observed when the influent contained $200 \mathrm{mg} / \mathrm{L}$ of $n Z V^{22}$. Ren et al..$^{23}$ found that $\mathrm{nZVI}$ could reduce anammox's start-up period by $33.2 \%$. The external magnetic field (MF) has also been reported to influence the metabolism of

\footnotetext{
${ }^{1}$ Shandong Provincial Key Laboratory of Soil Conservation and Environmental Protection \& Shandong Provincial Key Laboratory of Water Pollution Control and Resource Reuse, Linyi \& Qingdao, China. ${ }^{2}$ School of Environmental Science and Engineering \& Suzhou Research Institute \& Shenzhen Research Institute, Shandong University, Qingdao \& Suzhou \& Shenzhen, China. ${ }^{3}$ College of Chemistry and Chemical Engineering, Yantai University, Yantai, Shandong, China. ${ }^{4}$ Department of Soil and Environmental Sciences, Muhammad

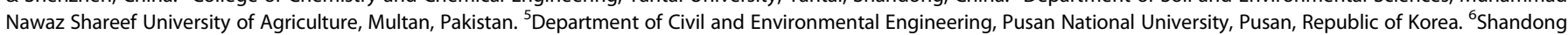

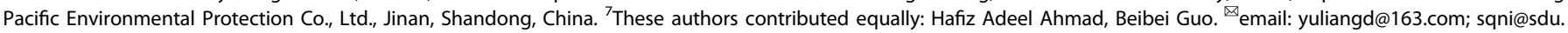
edu.cn
} 

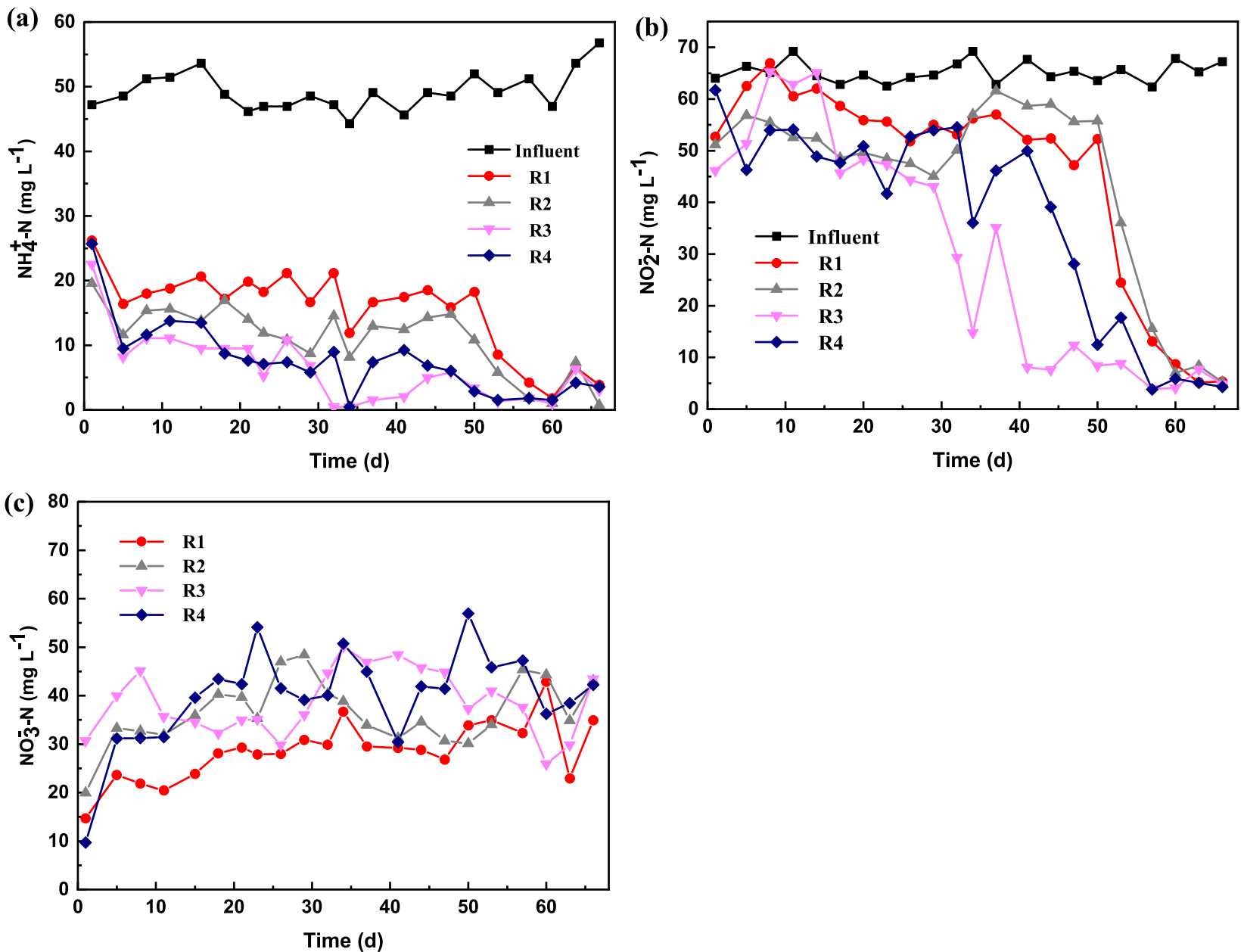

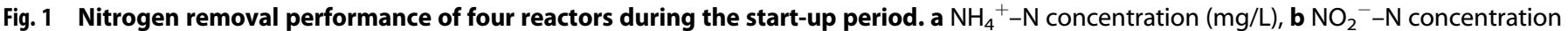
$(\mathrm{mg} / \mathrm{L}), \mathrm{c} \mathrm{NO}_{3}{ }^{-}-\mathrm{N}$ concentration $(\mathrm{mg} / \mathrm{L})$.

microorganisms negatively as well as positively ${ }^{24,25}$. The optimum range of MF strength may vary for each microbe. It was observed that MF strength of $30 \mathrm{mT}$ increased the relative abundance of Firmicutes, while decreased the content of Bacteroidetes ${ }^{25}$. Previously, the effect of different MF strengths ranged between 5 and $150 \mathrm{mT}$ was studied ${ }^{26-29}$, and it was reported that MF strength up to $70 \mathrm{mT}$ was better to improve the wastewater treatment performance ${ }^{27}$. The anammox activity was increased under the influence of externally applied weak MF until $75 \mathrm{mT}$, but a further increase in MF strength caused declination of anammox activity $^{27}$. The MF strength of $5 \mathrm{mT}$ has been observed as an activity enhancer of aerobic ammonium oxidizing bacteria $(A O B)^{28}$. Keeping in view the previous findings, it is proposed that the combined effects of low strength MF and nZVI, if appropriately optimized, may abbreviate the initiation time of anammox to provide resistance against the substrate shock. This research was aimed to appraise the coupled effects of low strength MF and $\mathrm{nZVI}$ on anammox start-up time and process stability. Concurrently, the impacts of nZVI and MF's combined application on the growth of other bacterial genera responsible for the nitrogen cycle were also studied. Anammox enrichment process was monitored by measuring different parameters, such as water quality (nitrite, nitrate, and ammonium in the influent and effluent), gene copy numbers of anammox, $A O B$, and denitrifying bacteria, and microbial community composition.

The objectives of this research are (1) to study the influence of sole and combined application of MF and nZVI on the start-up and performance stability of anammox, and (2) to explore their effects on microbial composition and gene copy number of nitrogenrelated bacteria. Interestingly, the synergistic partial-denitrification, anammox, and DNRA (SPDAD) processes were discovered in the system, opening a twilight for the complete nitrogen removal. This study's findings may provide an economical and efficient strategy to promote the anammox process's engineering application.

\section{RESULTS AND DISCUSSION}

\section{Start-up phase}

To avoid the toxic effect of higher nitrite concentration on microorganisms ${ }^{30}$, the influent $\mathrm{NH}_{4}{ }^{+}-\mathrm{N}$ and $\mathrm{NO}_{2}{ }^{-}-\mathrm{N}$ during the first 66 days was maintained at 50 and $60 \mathrm{mg} / \mathrm{L}$, respectively. The $\mathrm{NH}_{4}{ }^{+}-\mathrm{N}$ removal efficiency in each reactor reached up to $60 \%$ quickly with a certain amount of $\mathrm{NO}_{3}{ }^{-}-\mathrm{N}$ in the effluent. On the 5th day, the $\mathrm{NH}_{4}{ }^{+}-\mathrm{N}$ removal from reactors $\mathrm{R} 1-\mathrm{R} 4$ was $32.1,36.9$, 40.4, and $39.1 \mathrm{mg} / \mathrm{L}$ (Fig. 1a), respectively cumulative concentration of $\mathrm{NO}_{3}{ }^{-}-\mathrm{N}$ was $23.7,33.3,39.9$, and $31.1 \mathrm{mg} / \mathrm{L}$ in respective reactors (Fig. 1C). The higher concentration of $\mathrm{NO}_{3}{ }^{-}-\mathrm{N}$ might be due to the proliferation of nitrifying bacteria or lower denitrifying bacteria activity. It has also been reported that other bacteria, despite nitrite-oxidizing bacteria (NOB), carrying $n x r$ gene, can contribute to nitrate production from nitrite in an anammox reactor ${ }^{31}$. Besides, concentrations of $\mathrm{NO}_{2}{ }^{-}-\mathrm{N}$ in each reactor's effluent showed a different degree of an increasing trend. On the 11 th day, the $\mathrm{NO}_{2}{ }^{-}-\mathrm{N}$ concentration in the effluent of R1-R4 reached $60.5,52.6,62.8$, and $54.1 \mathrm{mg} / \mathrm{L}$, respectively (Fig. $1 \mathrm{~b}$ ). 

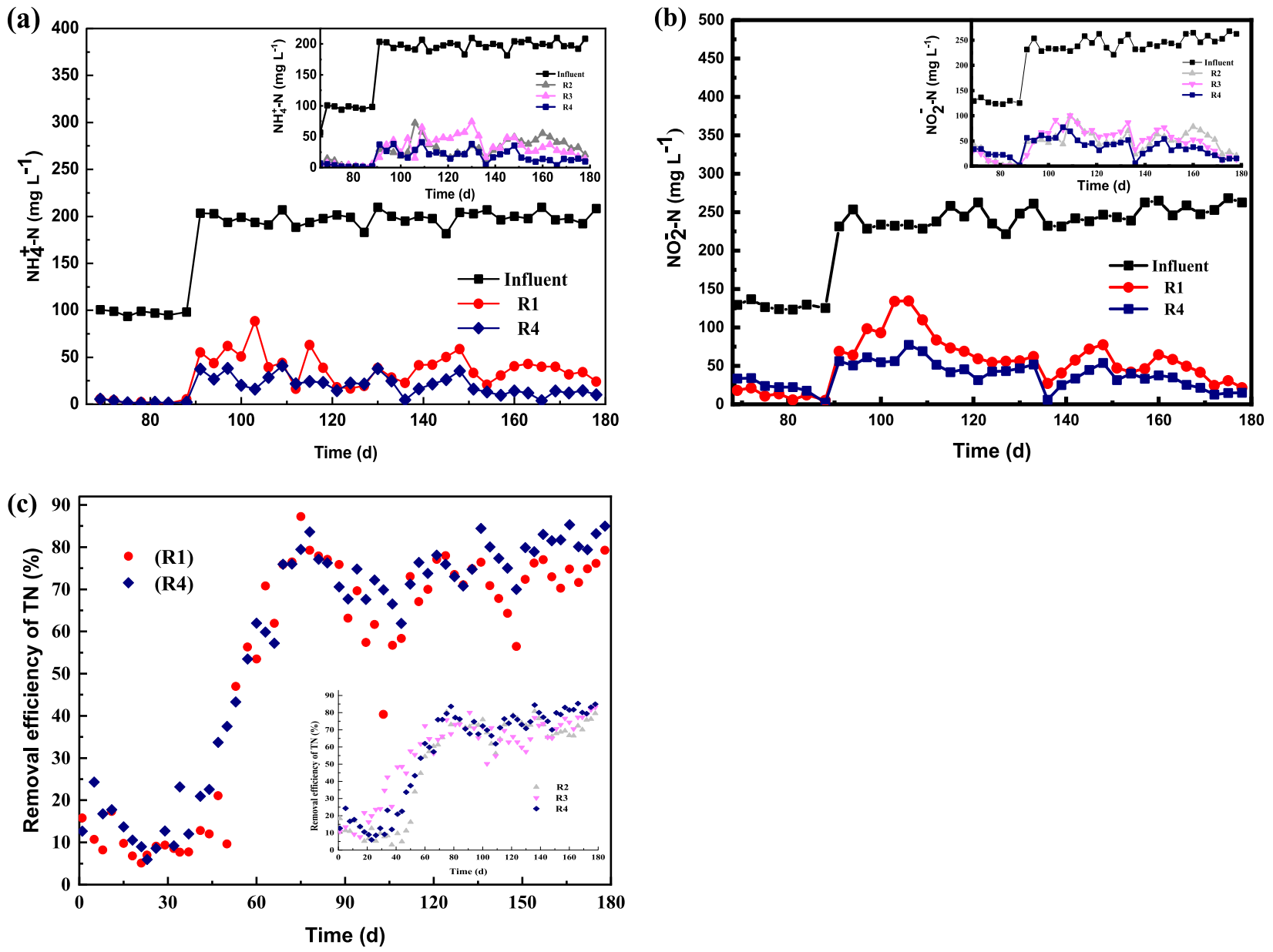

Fig. 2 Nitrogen removal performance of the four reactors in the stabilization period. a $\mathrm{NH}_{4}{ }^{+}-\mathrm{N}$ concentration $(\mathrm{mg} / \mathrm{L}), \mathbf{b} \mathrm{NO}_{2}{ }^{-}-\mathrm{N}$ concentration $(\mathrm{mg} / \mathrm{L})$, c removal efficiency $(\%)$ of total nitrogen.

Furthermore, the DO of each reactor was also monitored, and it was found that $\mathrm{DO}$ values of four reactors in the first 20 days were varied from 0.20 to $0.50 \mathrm{mg} / \mathrm{L}$. The oxygen half-saturation constant of $A O B$ has been reported in the range of $0.2-0.4 \mathrm{mg} / \mathrm{L}$, and the growth rate of $A O B$ can reach $0.5-1.0$ per day ${ }^{32}$. Thus, $A O B$ and archaea, and some NOB adapt to the lower DO concentration and could grow ${ }^{33-35}$. So, the higher $\mathrm{NO}_{3}{ }^{-}-\mathrm{N}$ values in the start-up phase can be justified by the growth of nitrifying bacteria and some other bacteria carrying the $n x r$ gene. However, as the incubation time increased, some bacteria which may not be adapted to the conditions might be degraded. The denitrifying bacteria could propagate on the carbon source provided by degraded biomass ${ }^{12}$. The use of $\mathrm{NO}_{x}{ }^{-}-\mathrm{N}$ by denitrifying bacteria contributed to the nitrogen removal rate (Figs. 1 and 2c) and can be called denitrifying propagation phase. Due to unfavorable environmental conditions, the degraded bacteria could have provided a carbon source for denitrification bacteria's growth ${ }^{13,14}$. It has been seen from Fig. $2 c$ that in the initial, nitrogen removal efficiency showed a decreasing trend, which is caused by consumption of endogenous organic matter, which slowly consumed and excluded the dominancy of the denitrification process. The conditions in the reactors are beneficial to anammox growth and eventually led to the washout of denitrifiers. The high TN removal in the latter phase was attributed to the enrichment of anammox abundance.

From the 29th day, the effluent concentrations of $\mathrm{NH}_{4}{ }^{+}-\mathrm{N}$ and $\mathrm{NO}_{2}{ }^{-} \mathrm{N}$ in $\mathrm{R} 3$ declined sharply, and the $\mathrm{NO}_{2}{ }^{-}-\mathrm{N}$ and $\mathrm{NH}_{4}{ }^{+}-\mathrm{N}$ removal ratio increased from 0.52 to 1.24 , close to the theoretical ratio of 1.32 , which indicates a rapid increase in the anammox bacterial activity ${ }^{5,36}$. The stoichiometric ratios of R1, R2, and R4 reached close to theoretical value on days 50, 50, and 41, respectively. The activity enhancing phase started around 22 days earlier in R3 when compared with R1, which clearly showed the positive effects of MF to short the start-up period of anammox. Though R4 showed a more extended start-up period than R3, it was still shorter when compared with R1. It was observed that R2 with the only $\mathrm{nZVI}$ did not show a clear difference from the control reactor. On the 34th day, the $\mathrm{NH}_{4}{ }^{+}-\mathrm{N}$ and $\mathrm{NO}_{2}{ }^{-}-\mathrm{N}$ removal rates of R3 were $95.5 \%$ and $88.1 \%$, respectively, which maintained at $85 \%$ from days 41 to 60 . Compared with the control, the start-up time of R3 was shortened from 60 days to 34 days under the action of MF, and the efficiency was increased by $43.3 \%$ in the start-up period. The start-up time of the reactor under the combined effects of $\mathrm{nZVI}$ and MF was $\sim 50$ days, and the efficiency increased by $16.7 \%$. On the other hand, the start-up time of anammox in R1 and R2 showed no noticeable difference.

\section{Reactors' performance under increased nitrogen loading}

After the successful start-up of all reactors, the influent $\mathrm{NH}_{4}{ }^{+}-\mathrm{N}$ and $\mathrm{NO}_{2}{ }^{-}-\mathrm{N}$ concentrations were increased progressively to observe the reactors' stability under different loading rates. As shown in Fig. 2, on day 69, the influent concentrations of $\mathrm{NH}_{4}{ }^{+}-\mathrm{N}$ and $\mathrm{NO}_{2}{ }^{-} \mathrm{N}$ were increased from 50 to $100 \mathrm{mg} / \mathrm{L}$ and 60 to $120 \mathrm{mg} / \mathrm{L}$ (nitrogen loading rate was $2.64 \mathrm{~kg} / \mathrm{L} / \mathrm{d}$ ), respectively. The response of $\mathrm{R} 2$ against increased $\mathrm{N}$ loading was almost comparable to R1. The concentration of effluent $\mathrm{NO}_{2}{ }^{-}-\mathrm{N}$ in $\mathrm{R} 1-\mathrm{R} 3$ was slightly increased. The removal performance of R4 was somewhat 


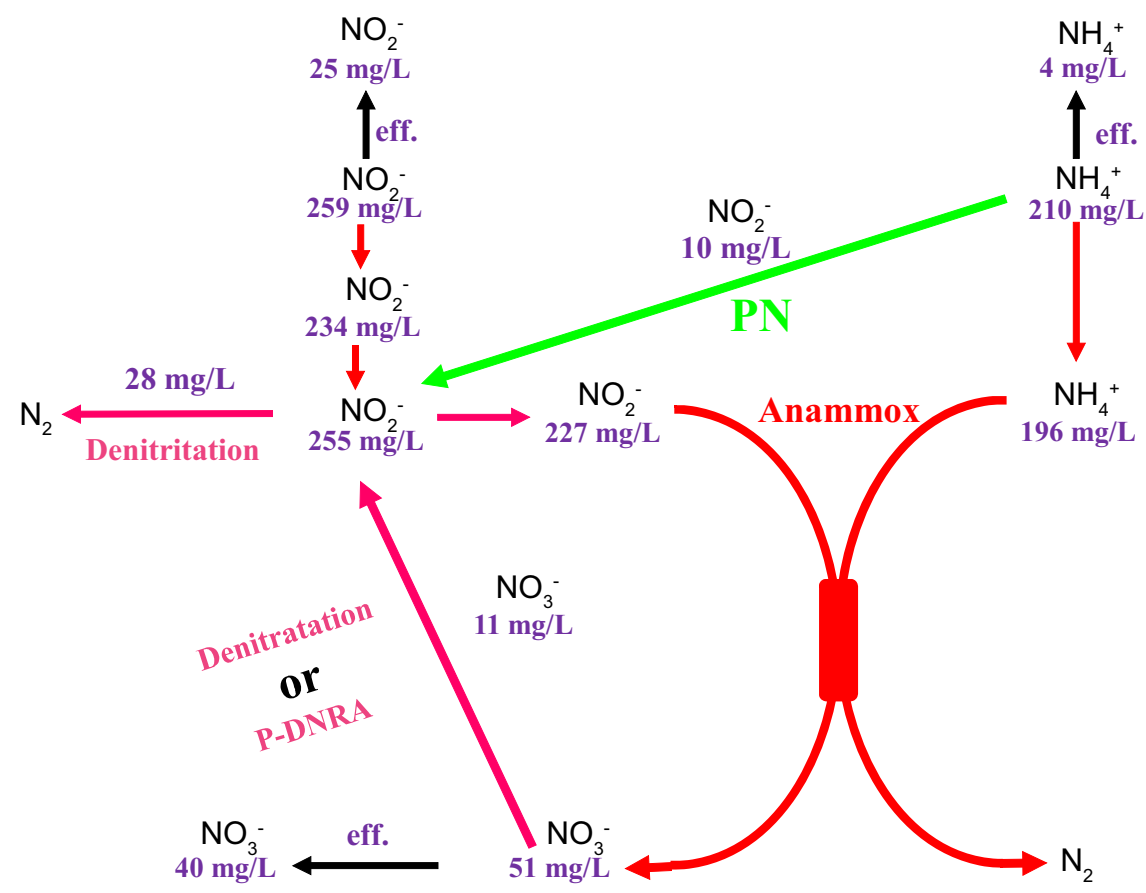

Fig. 3 Nitrogen mass balance of R4 on day 166. This mass balance is drawn on the base of anammox reaction stoichiometry. The black arrows showed the amount of nitrogen to effluent, the red lines indicated anammox process, the green line indicated partial nitrification process, and the pink arrows indicate partial denitrification or partial-DNRA process.

better than R1. Similarly, the removal of $\mathrm{NH}_{4}{ }^{+}-\mathrm{N}$ and $\mathrm{NO}_{2}{ }^{-}-\mathrm{N}$ in R4 was better than R3 (Fig. 2a, b). This implies that the increase in nitrogen loading does not have a deterioration impact on the operation of the four reactors after the successful build-up of anammox activity.

The influent concentration of $\mathrm{NH}_{4}{ }^{+}-\mathrm{N}$ and $\mathrm{NO}_{2}{ }^{-}-\mathrm{N}$ was again amplified to 200 and $240 \mathrm{mg} / \mathrm{L}$ (nitrogen loading rate was $5.28 \mathrm{~kg}$ / $\mathrm{m}^{3} / \mathrm{d}$ ) on the $91 \mathrm{st}$ day. After the second increment in $\mathrm{N}$ loading, the effluent $\mathrm{NH}_{4}{ }^{+}-\mathrm{N}$ concentration in $\mathrm{R} 1$ and $\mathrm{R} 4$ was increased to 69.2 and $56.3 \mathrm{mg} / \mathrm{L}$, respectively, and the effluent $\mathrm{NO}_{2}{ }^{-}-\mathrm{N}$ concentration was increased to 55.5 and $37.4 \mathrm{mg} / \mathrm{L}$ in $\mathrm{R} 1$ and $\mathrm{R} 4$, respectively. The increasing trend in effluent $\mathrm{NO}_{2}{ }^{-}-\mathrm{N}$ concentration in R1 was observed till the 106th day, and the highest value of effluent $\mathrm{NO}_{2}{ }^{-}-\mathrm{N}$ concentration was $134.8 \mathrm{mg} / \mathrm{L}$ which decreased the removal rate in R1 about $42.4 \%$. Likewise, considerable fluctuations were also observed in the removal rate of $\mathrm{NH}_{4}{ }^{+}-\mathrm{N}$, where more variation was noted in $\mathrm{R} 1$. A little higher nitrogen removal efficiency of R3 on day 91 (80\%) and on day 106 (71.18\%) were witnessed compared to R4 $(67 \%$ and $66 \%$, respectively). Similarly, a little high nitrogen removal efficiency was registered in R2 on days 88-91 and on days 97-100 as compared to R4. These variations might be caused due to the calculation error. The presence of $\mathrm{MF}$ and $\mathrm{nZVI}$ decreased the influence of substrate shock on the anammox performance. Although the removal rates of $\mathrm{NH}_{4}{ }^{+}-\mathrm{N}$ and $\mathrm{NO}_{2}{ }^{-}-\mathrm{N}$ in $\mathrm{R} 4$ were also decreased, but the fluctuation was slighter than R1 and R3. On the 115th day, the removal rates of $\mathrm{NH}_{4}{ }^{+}-\mathrm{N}$ and $\mathrm{NO}_{2}{ }^{-}-\mathrm{N}$ in $\mathrm{R} 4$ were recovered to over $80 \%$ and gradually reached over $90 \%$ afterward. Comparable results have also been observed by Wang et al. ${ }^{14}$ in ABBR. However, Chen et al. ${ }^{6}$ reported different results, which showed anammox was failed to adapt to the higher nitrogen loading rate. In addition, the increase in nitrogen loading also showed a negative impact on the nitrogen removal performance of R3. As shown in Fig. 2c, total nitrogen removal efficiency (about $80 \%$ ) of R4 was always better than other reactors from the 90th to 180th day.

Nitrogen mass balance (Fig. 3) on day 166 proved the coupling of nitrogen removal bacteria on the basis of reported anammox stoichiometric values of $\mathrm{NO}_{2}{ }^{-}-\mathrm{N}^{-} \mathrm{NH}_{4}{ }^{+}-\mathrm{N}$ (1.32) and $\mathrm{NO}_{3}{ }^{-}-\mathrm{N} /$ $\mathrm{NH}_{4}{ }^{+}-\mathrm{N}$ (0.26). So, if there is only an anammox process, ammonium and nitrite consumption should be around 196 and $258 \mathrm{mg} / \mathrm{L}$, respectively, to meet the reported stoichiometry of the anammox process and effluent nitrate concentration should be approximately $51 \mathrm{mg} / \mathrm{L}$. However, the stoichiometric values of $\mathrm{NO}_{2}{ }^{-}-\mathrm{N} / \mathrm{NH}_{4}{ }^{+}-\mathrm{N}$ and $\mathrm{NO}_{3}{ }^{-}-\mathrm{N} / \mathrm{NH}_{4}{ }^{+}-\mathrm{N}$ obtained in this study were around 1.15 and 0.19 , respectively, in $\mathrm{R} 4$ (coupled effects of $\mathrm{nZVI}$ and MF) on day 166 . This means, $227 \mathrm{mg} / \mathrm{L}$ of $\mathrm{NO}_{2}{ }^{-}-\mathrm{N}$ and $196 \mathrm{mg} / \mathrm{L}$ of $\mathrm{NH}_{4}{ }^{+}-\mathrm{N}$ consumed by anammox, and the remaining amount is removed by other nitrogen cycle bacteria. The $\mathrm{NH}_{4}{ }^{+}$, $\mathrm{NO}_{2}{ }^{-}$, and $\mathrm{NO}_{3}{ }^{-}$attributed to various groups of microorganisms by keeping R1 (1.15) and R2 (0.19) values by using Eqs. 4 and 5. Overall, the proposed nitrogen mass balance shows a clear coupling of anammox with other nitrogen cycle bacteria

\section{Effects of $\mathbf{n Z V I}$ and MF on the functional genes}

So as to study the combined effect of nZVI and MF on functional genes of anammox bacteria, the 16S rRNA gene copy numbers of anammox and other nitrogen cycle bacteria at different stages of the experiment were determined by the qPCR technique. The copy numbers of $h z o$ (hydrazine oxidoreductase) functional gene were also recorded.

The anammox $16 \mathrm{~S}$ rRNA copy number was increased gradually with time (Fig. 4a). Initially, the copy number of anammox $16 \mathrm{~S}$ rRNA was $1.01 \times 10^{6}$ copies/ng DNA. R1 had the lowest anammox copy number among the four reactors on the 60th day, 120th, and 180th day. The highest copy number of anammox 16S rRNA was recorded in $\mathrm{R} 4\left(2.13 \times 10^{6}\right)$, which was followed by R3 $\left(2.10 \times 10^{6}\right)$ and R2 $\left(1.70 \times 10^{6}\right)$ on the 60th day. Nevertheless, R4 and R3 have almost similar gene copy number on the 60th day, which made us propose that MF positively influence the anammox activity, which reduced the start-up period of anammox. It has been reported that bacterial activity is suppressed in the presence of incompatible nZVI concentrations $^{37-39}$. The adaptive capacity of microbes depends on the $n Z V I$ concentration ${ }^{40}$. The inhibition in anammox activity at 

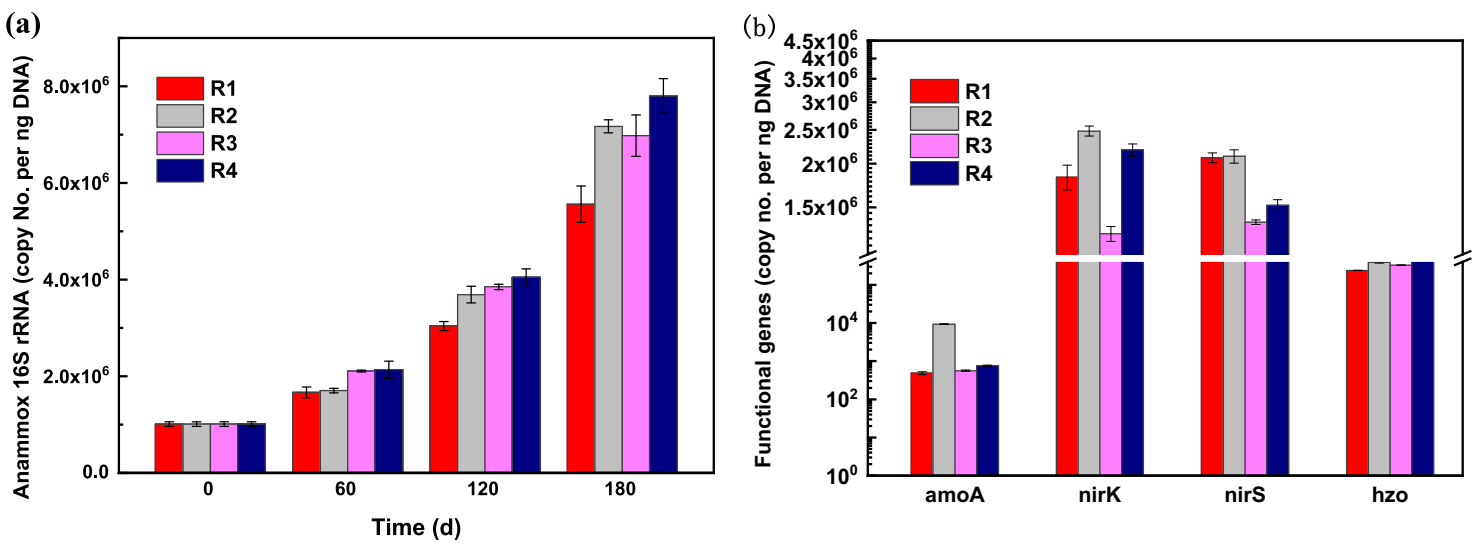

Fig. 4 The qPCR results of anammox enrichment process. a Anammox $16 \mathrm{~S}$ rRNA copy numbers at different days $(0,60,120$, and 180$)$ and $\mathbf{b}$ functional gene copy numbers of $\mathrm{AOB}$, denitrifying bacterial, and anammox on day 180. Data indicate average, and error bars represent standard deviation of the results from three independent samplings, each tested in triplicate.

higher $\mathrm{nZVI}$ concentration ( $3 \mathrm{~g} / \mathrm{L}$ in this experiment) is also supported by a comparable study ${ }^{41}$. Interestingly, at day 180 , the copy numbers of anammox $16 \mathrm{~S}$ rRNA in R2 $\left(7.17 \times 10^{6}\right.$ copies $/ \mathrm{ng}$ of DNA), R3 $\left(6.98 \times 10^{6}\right.$ copies/ng of DNA), and R4 $\left(7.8 \times 10^{6}\right.$ copies/ng of DNA) were significantly higher than R1 $\left(5.56 \times 10^{6}\right.$ copies/ng of DNA). It has also been claimed that the optimum concentration of $\mathrm{nZVI}$ can improve the proliferation of anammox cells after adaptation ${ }^{41}$. It is reported that $\mathrm{nZVI}$ lost the reactivity after 3 and 60 days in the presence and absence of oxygen in the wastewater treatment system, respectively ${ }^{42}$. It is an accepted fact the $\mathrm{nZVI}$ released $\mathrm{Fe}^{2+}$ and $\mathrm{H}_{2}$ in the solution ${ }^{43}$, which can be stored by anammox. Anammox can store iron ions for future haem synthesis and haem-containing enzymes involved in the electron transport chain ${ }^{44}$. Further, according to the previous study, the addition of $\mathrm{nZVI}$ enhanced the abundance of anammox bacteria $22,23,45$. The above explanation supports the conclusion about the higher anammox gene copy number in R2 in the later stage. Compared with R1, the percent increase of anammox gene copy numbers under a higher nitrogen loading rate were $29.0 \%, 25.5 \%$, and $40.3 \%$ in R2-R4, respectively, on day 180.

Further investigation was done to analyze the functional gene hzo of anammox and other nitrogen-cycle related bacteria in the reactors (Fig. 4b) on day 180. The co-existence of $A O B$ and denitrifying bacteria with anammox is reported to improve nitrogen removal efficiency ${ }^{46}$. The copy number of $h z o$ gene in R1-R4 were $2.39 \times 10^{5}$ and $3.87 \times 10^{5}, 3.29 \times 10^{5}$, and $4.01 \times 10^{5}$ copies/ng DNA, respectively. The coupled effects of nZVI and MF on anammox functional gene copy number were obvious, which might be responsible for the higher nitrogen removal under increasing nitrogen loading. The contents of amoA, nirK, and nirS in $\mathrm{R} 3$ were less, different from other reactors. The difference in amoA, nirK, and nirS gene copy numbers implies that microbes behave differently under the influence of MF. The optimum range of MF intensity is dissimilar for different microorganisms ${ }^{28,47}$, which can be considered a possible reason for the difference in gene contents among all four reactors. The lower nirk and nirS gene contents in R3 indicated that MF of this intensity (65 \pm $10 \mathrm{mT}$ ) might have inhibitory effects on denitrifying bacteria. Furthermore, higher nirk gene contents in R4 (nZVI+MF) originate a premise that $\mathrm{nZVI}$ might have neutralized the adverse effects of MF on denitrifying bacteria. As it can be seen from Fig. $4 \mathrm{~b}$, the denitrifying functional genes nirK and nirS were higher in $n Z V I$ reactor. Further, the lower amoA gene content signifies anammox and denitrifying bacteria as major contributors in nitrogen removal.
Table 1. The OTU numbers and bacterial diversity indices of sludge samples.

\begin{tabular}{|c|c|c|c|c|c|}
\hline \multirow[t]{2}{*}{ Sample } & \multirow[t]{2}{*}{ OTU numbers } & \multicolumn{2}{|c|}{$\begin{array}{l}\text { Community } \\
\text { richness }\end{array}$} & \multicolumn{2}{|c|}{ Community diversity } \\
\hline & & ACE & Chao 1 & Simpson & Shannon \\
\hline R1 & 1599 & 1600 & 1600 & 0.981 & 7.97 \\
\hline R2 & 1608 & 1839 & 1819 & 0.982 & 7.82 \\
\hline R3 & 1889 & 2180 & 2145 & 0.978 & 7.92 \\
\hline R4 & 1741 & 1750 & 1742 & 0.987 & 8.32 \\
\hline
\end{tabular}

\section{Effects of $\mathbf{Z Z V I}$ and MF on microbial communities}

It is an established fact that community structure and abundance considerably affect the stability and performance of the anammox process. Therefore, the community composition of the four reactors was analyzed after 180 days by high-throughput sequencing.

The sludge samples from all four reactors were collected at the end of the experiment, and operational taxonomic units (OTUs) and four indices (ACE, Chao1, Simpson, and Shannon) of each sample were calculated (Table 1). The OTUs varied from 1599 to 1889 for different treatments. The ACE and Chao1 indices reflect the community's richness, while Simpson and Shannon's indices reflect the community's diversity ${ }^{48}$. Generally speaking, the greater the Chao1 or ACE index, the higher the abundance of the community. The Shannon diversity index comprehensively considers the richness and uniformity of the community. The higher the Shannon index value, the higher the diversity of the community. The Simpson index is also one of the commonly used indexes for evaluating community diversity. The higher the Simpson index value, the higher the community diversity. The value of ACE (1600) and Chao1 (1600) indices of R1 was the minimum in four reactors reflecting the lowest community richness in R1. On the other hand, the maximum community richness was observed in R3 (MF reactor) as reflected by the highest value of ACE (2180) and Chao1 (2145) indices followed by $\mathrm{R} 2$ ( $\mathrm{nZVI}$ reactor) and R4 (nZVI + MF reactor). In short, the effect of MF on community richness was more pronounced than the effect of $\mathrm{nZVI}$ and the combination of $\mathrm{nZVI}$ and MF. The Simpson indices of all samples were not different. However, the Shannon indices of R4 were slightly higher than other samples, which showed a little higher diversity of community than other reactors.

The effects of $\mathrm{nZVI}$ and MF treatments on community structure distribution of sludge samples at different classification levels are presented in Fig. 5. The Chloroflexi, Proteobacteria, Cholorobi, and 

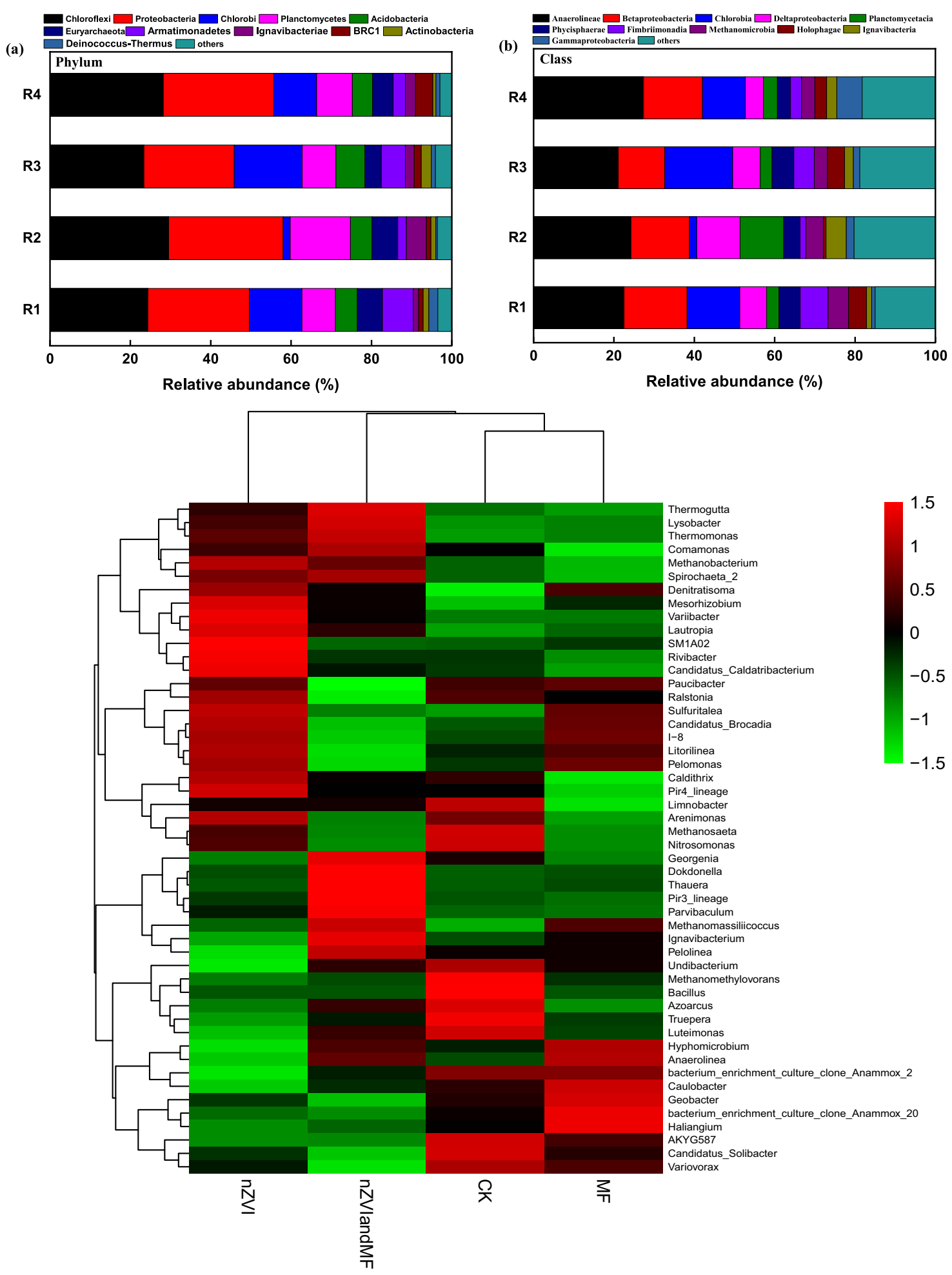

Fig. 5 The microbial community structure of sludge samples. a Top 12 abundant phyla at the phylum level, b top 11 abundant classes at class level, and $\mathbf{c}$ heat map of top 50 genera at the genus level.

Planctomycetes were the abundant phyla in all samples with little variation among different treatments (Fig. 5a). The presence of phyla such as Chloroflexi, Proteobacteria, and Cholorobi in an anammox reactor was also reported previously ${ }^{49}$. Relative abundance of Chloroflexi in R1-R4 was $24.3 \%, 29.5 \%, 23.4 \%$ and $30.0 \%$, respectively. The phylum Chloroflexi has also been detected in the anammox reactor and single-step autotrophic nitrogen removal system ${ }^{50,51}$. Some genera's proposed role belongs to
Chloroflexi in the anammox reactor is to consume the dead organic material and avoid their accumulation ${ }^{52}$. The relative abundance of Proteobacteria in R1-R4 was $25.2 \%, 28.5 \%, 22.5 \%$, and $27.5 \%$, respectively. According to the previous literature, mostly nitrifying and denitrifying bacteria (Thauera, Denitratisoma, and Geobacter) belong to the phylum Proteobacteria and could use $\mathrm{NO}_{2}{ }^{+}-\mathrm{N}$ and $\mathrm{NH}_{4}^{+}-\mathrm{N}$ for their metabolism and proliferation activities $^{4}$. As far as the relative abundance of phylum 


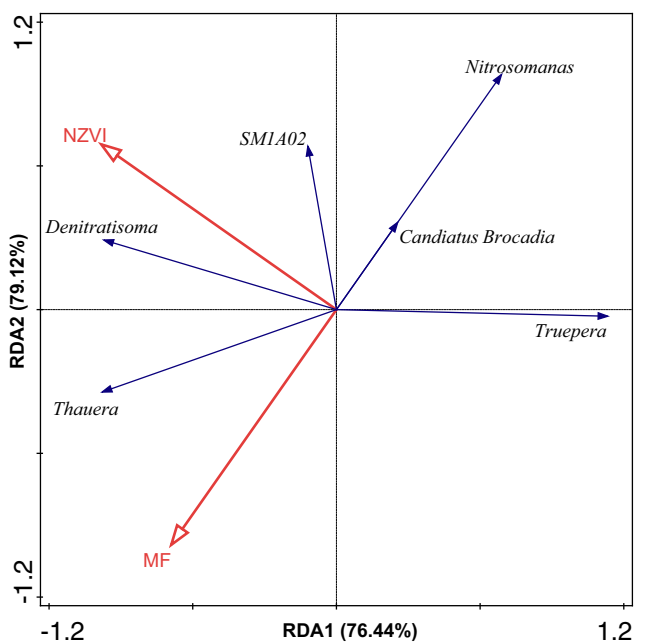

Fig. 6 The redundancy analysis (RDA) based on functional species. The RDA plot showed the correlation between the relative abundance of functional species and environmental parameters (nZVI and MF).

Planctomycetes in different reactors is concerned, no significant difference in R1 (8.4\%), R3 (8.4\%), and R4 (8.5\%) was noted in this regard (chi test, $p<0.01$. But, significantly higher (chi test, $p<0.01$ ) relative abundance (10.9\%) of Planctomycetacia in R2 clearly indicated the positive effects of $\mathrm{nZVI}$ on the anammox-related class Planctomycetacia R1 (3\%), R3 (2.9\%), and R4 (3.5\%) after adaptation of sludge to nZVI (Fig. 5b). The Planctomycetacia is an important class that contains anammox bacteria such as Candidatus Brocadia ${ }^{53}$ while class Betaproteobacteria $(15.7 \%$ in $\mathrm{R} 1,14.6 \%$ in $\mathrm{R} 2,11.5 \%$ in $\mathrm{R} 3$, and $14.6 \%$ in R4) contain many nitrifying, denitrifying and other nitrogen-related bacteria. Other dominated classes in R1-R4 were Anaerolineae (22.5\%, 24.3\%, $21.1 \%$, and $27.4 \%)$, Chlorobia (13.1\%, $1.8 \%, 16.9 \%$, and $10.7 \%)$, Ignavibacteria $(1.3 \%, 5 \%, 2.2 \%$, and $5 \%)$, Phycisphaerae $(5.3 \%, 4.0 \%$, $5.4 \%$, and 3.2\%). However, the role of Anaerolineae, Chlorobia, Phycisphaerae in anammox reactor is not confirmed yet. With regard to Ignavibacteria, it is reported that the player of class Ignavibacteria might have the ability to performed partial DNRA bacteria $^{15,17}$.

The key OTUs (top 50 genera) were selected and analyzed using a heat map to know the in-depth community structure of four reactors (Fig. 5c). The color reflects the abundance of OTUs in the corresponding sample (green indicated lower abundance and red showed higher abundance). The OTUs associated with Candidatus Brocadia were more abundant in R2 and R3, while less abundant in R1 and R4. But, in terms of nitrogen removal efficiency, R4 showed the highest removal efficiency, thanks to synergetic bacteria coexistence such as DNRA and denitrifiers. The difference of anammox abundance may be caused due to the difference in the ecological niche and physiological characteristics of anammox genera $^{54}$. The proliferation of other nitrogen-cycle related bacteria such as nitrifiers, denitrifiers, and DNRA played an essential role in increasing the nitrogen removal of anammox reactor ${ }^{55-57}$. The Nitrosomonas is the dominant AOB and was more abundant in R1 and R2. The denitrifying genus Thauera had a higher relative abundance in R4 than R1-R3. The abundance of Geobacter was higher in R3 and R1, while Ignavibacterium was more abundant in R4. The genera included Thauera and Denitratisoma are denitrifying genera ${ }^{58,59}$, and Geobacter has reported DNRA bacteria which can reduce nitrate into ammonium ${ }^{60-62}$. The genus Ignavibacterium is also responsible for the P-DNRA process ${ }^{17}$. Overall, the diversity of microbial genera involving anammox bacteria such as Candidatus Brocadia has the ability to perform the DNRA process $^{16,54,63}$. As it can be seen from Fig. 5a, b, Proteobacteria and Planctomycetes were among the abundant phyla, respectively. Thus, the denitrifying bacteria (Thauera and Denitratisoma), DNRA (Geobacter and Ignavibacterium), and anammox were co-existed in R4 with more abundance.

According to the literature, Thauera is mostly autotrophic denitrifying bacteria, which can be used for short-cut denitrification (only conversion of $\mathrm{NO}_{3}{ }^{-}-\mathrm{N}$ to $\mathrm{NO}_{2}{ }^{-}-\mathrm{N}$ ) ${ }^{53,64,65}$. The role of partial denitrification cannot be ruled out in the anammox reactor $^{5,66-68}$. The Denitratisoma performed the reduction of $\mathrm{NO}_{3}{ }^{-}-\mathrm{N}^{63}$ and was also reported as heterotrophic denitrifying bacteria in an anammox reactor. The DNRA bacteria might fuel the anammox process with the conversion of $\mathrm{NO}_{3}{ }^{-}$to $\mathrm{NH}_{4}{ }^{+69}$. Although anammox enrichment was carried out with synthetic wastewater, the presence of denitrifying bacteria is the same as in earlier reports ${ }^{70,71}$. In this study, $\mathrm{NO}_{3}{ }^{-} \mathrm{N}$ produced from anammox reaction is considered as an essential substrate for denitrifying and DNRA bacteria. Further, the decay of biomass under the pressure of unfavorable environmental conditions is inevitable. Also, the extracellular polymeric substances released by anammox and other bacteria provide the organic matter for reducing NO3-- $\mathrm{N}$ and NO2--N by denitrifying bacteria (44) and converting $\mathrm{NO}_{3}{ }^{-}-\mathrm{N}$ or $\mathrm{NO}_{2}{ }^{-}-\mathrm{N}$ to $\mathrm{NH}_{4}{ }^{+}$by DNRA bacteria ${ }^{15}$. Thus, a synergistic partial-denitrification, anammox, and DNRA (SPDAD) process was created coincidentally.

The correlation between the relative abundance of nitrogenrelated functional genera and external forces was performed by redundancy analysis (RDA) (Fig. 6). The angle of the arrow represents the correlation between functional genera and external treatment. The DNRA bacteria were excluded in the RDA analysis plot because of their very low abundance. The RDA analysis showed that the genus Denitratisoma and Thauera positively correlated while genera Nitrosomonas and Truepera negatively correlated with nZVI and MF. The Candidatus Brocadia negatively correlated with both factors. The PCA analysis revealed the microbial communities' difference between R1-R4 (Fig. S2). PCA analysis showed the difference and similarity of microbial community composition. Although nitrogen removal performance of R1 and R3 was different but R1 and R3 cluster together while R2 and R4 make their own distinct cluster. The results showed that $\mathrm{nZVI}$ caused the shift in the microbial community as compared to $\mathrm{MF}$ since two reactors containing $\mathrm{nZVI}$ have distinct microbial communities.

To gain deep insight into the molecular functions of microbiota in all four reactors, PICRUSt was used to envisage the changes in microbial function. The accessible annotated genes were imputed within the Kyoto Encyclopedia of Genes and Genomes (KEGG). Based on the KEGG analysis (Fig. 7), the lowest abundance was observed for the gene related to the biosynthesis of secondary metabolites, while higher abundance was observed for the gene related to energy, carbohydrate, and amino acid metabolism. Overall, there was not a clear difference in the abundance of the functional gene under different treatments except functional gene related to lipid metabolism, which was suppressed by MF. However, PICRUSt is associated with limitations such as this analysis depends on the accessibility of the reference genome in the database, which must be considered in future studies. Further, the gene might not be expressed, limiting the impact of their annotated functions. So, the microbial function derived from PICRUSt should be considered as the hypothesis that must be validated through in-depth functional assays.

\section{Significance and practical implementation of synergistic partial-denitrification, anammox, and DNRA (SPDAD) process}

The noticeable resistance by anammox to higher nitrogen loading shock in R4 can be justified by the growth of denitrifying bacteria (Thauera), responsible for the reduction of $\mathrm{NO}_{3}{ }^{-}$to $\mathrm{NO}_{2}{ }^{-}$and 


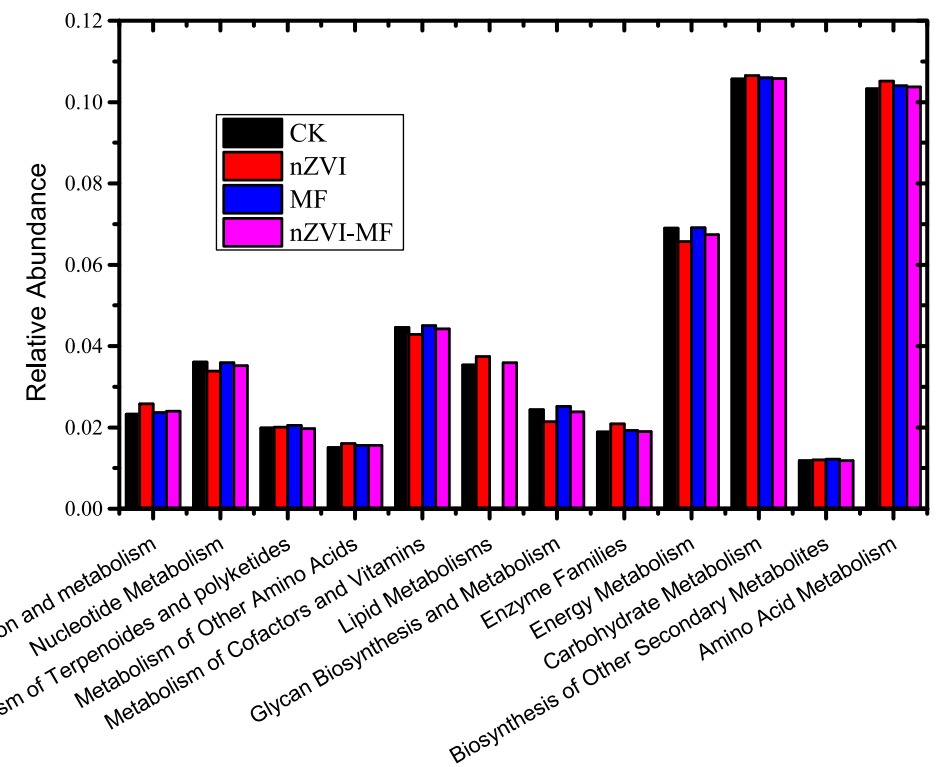

Fig. 7 The prediction of community functions based on KEGG analysis. The $x$-axis showed the second level metabolic functional genes and the $y$-axis showed the relative abundance of each functional gene.

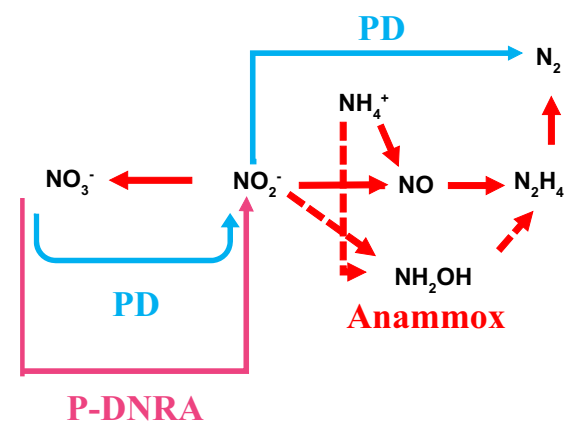

Fig. 8 Illustration of synergistic relationship of anammox-DNRAPD (SPDAD). Blue arrows showed the PD process, red arrows showed anammox reaction, and pink arrows showed the partialDNRA process.

DNRA bacteria (Geobacter and Ignavibacterium), responsible for the reduction of $\mathrm{NO}_{3}{ }^{-}$or $\mathrm{NO}_{2}{ }^{-}$to $\mathrm{NH}_{4}{ }^{+}$in anammox reactor. Overall, possible inter-relationship among anammox, DN, and DNRA bacteria were depicted in Fig. 8. Anammox can produce NO or $\mathrm{NH}_{2} \mathrm{OH}$ from $\mathrm{NO}_{2}{ }^{-}$with the little amount of $\mathrm{NO}_{3}{ }^{-}$. $\mathrm{NO}$ or $\mathrm{NH}_{2} \mathrm{OH}$ was further reduced to $\mathrm{N}_{2} \mathrm{H}_{4}$ and finally converted into $\mathrm{N}_{2}$. As seen from the qPCR analysis, $\mathrm{NO}_{2}{ }^{-}$respiratory genes nirS and nirk, which convert $\mathrm{NO}^{2}-$ into $\mathrm{NO}$ (an intermediate product of anammox metabolism), existed in all reactors. $\mathrm{NO}_{2}^{-}$is the essential substrate of anammox and an inhibitor if it presents in a higher concentration. So, denitrifying bacteria and DNRA bacteria may provide the shield to anammox bacteria from the substrate's inhibitory effects. Nevertheless, PD and DNRA can also use $\mathrm{NO}_{2}{ }^{-}$and can affect the removal efficiency negatively. So, it was assumed that the careful selection of environmental factors could improve the performance of anammox nitrogen removal with the association of other nitrogen cycle genera. Keren et al. ${ }^{15}$ also enriched anammox without any external carbon and observed the growth of denitrifying and DNRA bacteria where an overgrowth of DNRA bacteria decreased the performance of anammox bacteria. However, in this study, the nitrogen removal efficiency was higher in the presence of other nitrogen players, which means other nitrogenous bacteria positively influence the nitrogen removal performance of anammox. Some bacteria in the complex microbial community depend on the metabolites of other bacteria $^{52}$. The possible reason for PD and DNRA bacteria's growth is that the decaying biomass of some bacteria and EPS and some vitamins produced by anammox bacteria can be used by PD and DNRA as carbon sources. It has also been reported that the bacteria performing the DNRA process were also capable of performing the PD process ${ }^{15}$. The performance of SPDAD was more apparent in R4 (nZVI-MF as an external factor) than in other reactors. This phenomenon was observed coincidentally in this study; therefore, further exploration is needed to optimize the growth conditions and external environmental factors for a synergistic relationship among anammox, PDN, and DNRA bacteria. Overall, the diverse community of anammox, PDN, and DNRA will be the right choice for the complete removal of nitrogen from wastewater. SPDAD process may be suitable for the treatment of wastewaters loaded with a high concentration of $\mathrm{NO}_{3}{ }^{-}$. DNRA bacteria can provide $\mathrm{NH}_{4}{ }^{+}$and $\mathrm{NO}_{2}{ }^{-}$to anammox from $\mathrm{NO}_{3}{ }^{-}$and $\mathrm{DN}$ bacteria can generate $\mathrm{NO}_{2}^{-}$if a careful selection of environmental conditions can be achieved. Also, anammox itself has the ability to perform the DNRA process ${ }^{16}$.

This study unfolded the effects of external factors on the performance and microbial community of anammox. The MF was an effective external force to stimulate the anammox growth and shorten the start-up period by $43.3 \%$. nZVI addition did not show considerable effects on the reduction of the start-up period. However, in a later stage, nZVI showed a positive influence on anammox growth. The combination of $\mathrm{nZVI}$ and MF shortened the start-up time by $16.7 \%$ and improved the anammox stability under a high nitrogen loading rate. The results of QPCR showed that $\mathrm{nZVI}$ coupled with MF enhanced the proliferation and community diversity. The presence of DNRA (Ignavibacterium, Geobacter) and denitrifying bacterial genera (Thauera and Denitratisoma) may also support the removal of nitrogen. This study shows a twilight for the complete nitrogen removal via synergistic partial-denitrification, anammox, and DNRA process (SPDAD).

\section{MATERIALS AND METHODS}

\section{Origin of the sludge and synthetic medium}

The seed sludge utilized in this study was anaerobic granular sludge taken from working up-flow anaerobic sludge blanket reactor in Linyi City, China, and was stored in the laboratory for about 6 months. Before inoculating 
the bioreactors, the seed sludge was washed with tap water until the water became transparent and then with phosphate buffer $(0.2 \mathrm{M}, \mathrm{pH}=7.2)$. The one-fifth of each reactor's effective volume was filled with inoculum (mixed liquor volatile suspended solids (MLVSS) concentration of $8000 \pm$ $100 \mathrm{mg} / \mathrm{L}$ ). The anammox nutrient medium was prepared by $\mathrm{FeSO}_{4} \cdot 7 \mathrm{H}_{2} \mathrm{O}$ $(5 \mathrm{mg} / \mathrm{L}), \mathrm{KH}_{2} \mathrm{PO}_{4}(27 \mathrm{mg} / \mathrm{L}), \mathrm{MgSO}_{4}(120 \mathrm{mg} / \mathrm{L})$, and $\mathrm{CaCl}_{2}(180 \mathrm{mg} / \mathrm{L})$ with trace element's solution. The trace element solution was prepared ${ }^{72}$ and added in the mineral medium at a concentration of $1.0 \mathrm{ml} / \mathrm{L}$. Also, $\left(\mathrm{NH}_{4}\right)_{2} \mathrm{SO}_{4}$ and $\mathrm{NaNO}_{2}$ were used to supplement $\mathrm{NH}_{4}{ }^{+}-\mathrm{N}$ and $\mathrm{NO}_{2}{ }^{-}-\mathrm{N}$, respectively, while $\mathrm{KHCO}_{3}(500 \mathrm{mg} / \mathrm{L})$ was added to fulfill the requirement of inorganic carbon.

\section{Continuous experiments}

Four bioreactors (R1-R4), each reactor working volume of $1.0 \mathrm{~L}$, were designed for continuous experiments (Fig. S1). The reactor R1 was operated as a control without $\mathrm{nZVI}$ and MF. The reactors R2 and R3 were employed to assess the impacts of $\mathrm{nZVI}$ and MF on the anammox process by adding $3.0 \mathrm{~g} / \mathrm{L} \mathrm{nZVI}$ to the reactor at the initial of the experiment as reported $^{23}$ and applying an MF strength of $65 \pm 10 \mathrm{mT}$, which was modified from the literature were reported that anammox performed well up to $70 \pm 10 \mathrm{mT}^{27}$, respectively. The MF was applied by placing two permanent magnets $(1.5 \times 5 \times 10 \mathrm{~cm})$ along the two sides of the respective reactor. The reactor R4 was designed to evaluate the combined effect of $\mathrm{nZVI}(3.0 \mathrm{~g} / \mathrm{L})$ and external MF $(65 \pm 10 \mathrm{mT})$. The $\mathrm{nZVI}$ powder $(60 \mathrm{~nm}$, purity $\geq 99 \%$ ) was acquired from Aladdin Industrial Inc. Shanghai, China. The strength of MF was measured by a tesla meter (SJ700).

The hydraulic retention time (HRT) of $12 \mathrm{~h}$ was maintained by using the rotation of the peristaltic pump $(0.5 \mathrm{rpm})$. The nitrogen loading was increased stepwise according to the performance of reactors. The reactor performance was divided into three phases: start-up phase, process stability phase, and increasing nitrogen loading phase. The nitrogen loading was elevated by increasing influent $\mathrm{NH}_{4}{ }^{+}-\mathrm{N}$ and $\mathrm{NO}_{2}{ }^{-} \mathrm{N}$ concentration without changing HRT $(12 \mathrm{~h})$. The operating temperature was controlled at $32 \pm 1{ }^{\circ} \mathrm{C}$ by a water bath. The reactors were wrapped with silver paper to avoid the growth of phototrophic bacteria. The influent container was purged with high purity nitrogen gas twice a day to remove the dissolved oxygen (DO).

\section{Analytical methods}

The influent and effluent of all reactors were analyzed for ammonium, nitrite, and nitrate after filtration with a $0.45 \mu \mathrm{m}$ syringe filter described in the standard methods ${ }^{73}$. The total nitrogen removal efficiency was measure according to the equation given below

$\operatorname{NRE}(\%)=\mathrm{TN}_{(\text {in) }}-\mathrm{TN}_{(\text {out }} / \mathrm{TN}_{(\text {in) }} * 100$

where $\mathrm{TN}_{\mathrm{in}}$ is the summation of nitrogen fraction concentrations in the influent, $\mathrm{TN}_{\text {out }}$ is the summation of nitrogen fraction concentrations in the effluent

The sludge mixed liquor suspended solids and the MLVSS were measured following the standard methods ${ }^{73}$. The digital pH meter (PHS3C, Leici, China) and portable DO meter (HQ40d, Hach, America) were used to measure the $\mathrm{pH}$ and $\mathrm{DO}$, respectively in the reactor as well as in the influent tank.

Hypothetically, the nitrogen mass balance was drawn based on Eqs. 4 and 5, which modified from Eqs. 2 and 3.

$$
\begin{aligned}
& \mathrm{r} 1=\left(\mathrm{NO}_{2}^{-}\right)_{\text {in }}-\left(\mathrm{NO}_{2}^{-}\right)_{\text {out }} /\left(\mathrm{NH}_{4}^{+}\right)_{\text {in }}-\left(\mathrm{NH}_{4}^{+}\right)_{\text {out }} \\
& \mathrm{r} 2=\left(\mathrm{NO}_{3}^{-}\right)_{\text {out }} /\left(\mathrm{NH}_{4}^{+}\right)_{\text {in }}-\left(\mathrm{NH}_{4}^{+}\right)_{\text {out }}
\end{aligned}
$$

$\mathrm{r} 1$ is consumed $\mathrm{NO}_{2}{ }^{-}$to consumed $\mathrm{NH}_{4}{ }^{+}$ratio by anammox, while $\mathrm{r} 2$ means produced $\mathrm{NO}_{3}^{-}$to consumed $\mathrm{NH}_{4}^{+}$ratio by anammox. $\mathrm{r} 1$ and r2 should be around 1.32 and 0.26 , respectively, if there is the only anammox. However, in this study, $\mathrm{r} 1$ and 2 were 1.15 and 0.19 , respectively. So, new equations (Eqs. 4 and 5) were derived by using Eqs. 2 and 3. The $\mathrm{NH}_{4}{ }^{+}, \mathrm{NO}_{2}^{-}$, and $\mathrm{NO}_{3}{ }^{-}$attributed to various microorganism's groups by keeping $\mathrm{r}^{\prime \prime}(1.15)$ and $\mathrm{r}^{\prime}$ (0.19) values.

$$
\mathrm{r}^{\prime}=\left(\mathrm{NO}_{2}^{-}\right)_{\text {in }}-\left[\left(\mathrm{NO}_{2}^{-}\right)_{\text {out }}+\left(\mathrm{NO}_{2}^{-}\right)_{\mathrm{DN}}\right] /\left(\mathrm{NH}_{4}^{+}\right)_{\text {in }}-\left[\left(\mathrm{NH}_{4}^{+}\right)_{\text {out }}+\left[\left(\mathrm{NH}_{4}^{+}\right)_{\mathrm{PN}}\right]\right.
$$

$\mathrm{r}^{\prime}=\left(\mathrm{NO}_{3}^{-}\right)_{\text {amx. }}-\left[\left(\mathrm{NO}_{3}^{-}\right)_{\mathrm{DNorP}-\mathrm{DNRA}} /\left(\mathrm{NH}_{4}^{+}\right)_{\text {in }}-\left[\left(\mathrm{NH}_{4}^{+}\right)_{\text {out }}+\left[\left(\mathrm{NH}_{4}^{+}\right)_{\mathrm{PN}}\right]\right.\right.$
The $\left(\mathrm{NO}_{2}^{-}\right)_{\mathrm{DN}}$ is the proposed $\mathrm{NO}_{2}{ }^{-}$removed by denitrification, $\left(\mathrm{NH}_{4}{ }^{+}\right)$ PN is the proposed $\mathrm{NH}_{4}^{+}$used by partial nitrifying bacteria, and $\left(\mathrm{NO}_{3}{ }^{-}\right)$ DN or P-DNRA is proposed $\mathrm{NO}_{3}{ }^{-}$consumed by P-DNRA or denitrification.

\section{Quantitative PCR (qPCR)}

The biomass samples were collected from each bioreactor at constant intervals $(0,60,120$, and 180 days after the start of the experiment) to analyze anammox gene copy numbers. According to the isolation kit manual, total genomic DNA from a $0.5 \mathrm{~g}$ wet sludge was taken out using the Powder Soil ${ }^{\text {mit }}$ DNA Isolation Kit (MO BIO Laboratories, USA). The quality and concentration of the extracted DNA were determined with a microspectrophotometer (K5500, Kaiao, China). Finally, the copy numbers of the $16 \mathrm{~S}$ rRNA gene of anammox bacteria were quantified by qPCR analysis. In addition, the functional gene of ammonia-oxidizing bacteria (amoA gene), anammox (hzo genes), and denitrifying bacteria (nirS and nirk gene) at the DNA level were also quantified. Specific primers (Table S1) and qPCR conditions (Table S2) can be seen in Supplementary Materials. The reaction mixture (total reaction volume of $20 \mu \mathrm{L}$ ) was included of SYBR Premix Ex Taq $(10 \mu \mathrm{L})$, either $1.0 \mu \mathrm{L}$ extracted DNA or $10^{1}-10^{8}$ copies per well of the standard vector plasmid, RNase-free water $(8.2 \mu \mathrm{L}), 5 \mu \mathrm{mol} / \mathrm{mL}$ reverse primers $(0.4 \mu \mathrm{L})$, and $5 \mu \mathrm{mol} / \mathrm{mL}$ forward primers $(0.4 \mu \mathrm{L})$. The Light Cycler 480 II (Roche, Switzerland) was used for PCR amplifications and quantifications. The results are based on triplicate analysis, and the standard deviation is less than $5 \%$. The student $t$ test was applied to verify the significance of the results.

\section{High-throughput sequencing analysis}

The samples for high-throughput sequencing were collected from the reactors on the 180th day. The DNA was extracted as described in Section "Significance and practical implementation of synergistic partial-denitrification, anammox, and DNRA (SPDAD) process". The extracted DNA from all reactors was amplified, and the quality of DNA was detected with agarose gel electrophoresis (genomic DNA: $1 \%$ of gel concentration. Voltage $100 \mathrm{~V}$, and $40 \mathrm{~min}$ of electrophoresis time before sequencing; PCR products: gel concentration of $2 \%$, voltage $80 \mathrm{~V}$, and electrophoresis time $40 \mathrm{~min}$ ). The concentration, fragment size, purity, and completeness of the sample genome and amplified products were detected. The results have shown apparent single bands. Afterward, Illumina MiSeq sequencing was performed by Shanghai Personal Biotechnology Co., Ltd. (Shanghai, China) for microbial structure and abundance. The SPSS13.0 (IBM, USA) software was applied for general statistical analysis and a chi-square test. Then Excel (Microsoft Office) was used to convert chi-square values into $p$ values to indicate the significance ${ }^{74}$.

The RDA was performed to determine the correlation between functional species and experiment factors (MF and nZVI) using the software CANOCO. The variations in the metabolic pathways were anticipated by phylogenetic investigation of communities by reconstructing unobserved states (PICRUSt) ${ }^{75}$. The principal component analysis at the genus level about the structure of community composition was carried out with $\mathrm{R}$ software, and two-dimensional analyses described natural distribution characteristics.

\section{Reporting summary}

Further information on research design is available in the Nature Research Reporting Summary linked to this article.

\section{DATA AVAILABILITY}

The data that support the findings of this study are available from the corresponding author upon reasonable request. The 16S rRNA gene sequences obtained in this study were submitted to the NCBI Sequence Read Archive (SRA) under accession numbers SAMN19033387-SAMN19033390.

Received: 9 October 2020; Accepted: 21 May 2021; Published online: 14 June 2021

\section{REFERENCES}

1. Lackner, S. et al. Full-scale partial nitritation / anammox experiences- an application survey. Water Res. 55, 292-303 (2014). 
2. Wang, B., Guo, Y., Zhao, M., Li, B. \& Peng, Y. Achieving energy-efficient nitrogen removal and excess sludge reutilization by partial nitritation and simultaneous anammox denitrification and sludge fermentation process. Chemosphere 218, 705-714 (2019).

3. Mulder, A., van de Graaf, A. A., Robertson, L. A. \& Kuenen, J. G. Anaerobic ammonium oxidation discovered in a denitrifying fluidized bed reactor. FEMS Microbiol. Ecol. 16, 177-183 (1995).

4. Cao, Y., van Loosdrecht, M. C. M. \& Daigger, G. T. Mainstream partial nitritation-anammox in municipal wastewater treatment: status, bottlenecks, and further studies. Appl. Microbiol. Biotechnol. 101, 1365-1383 (2017).

5. Star, W. R. L. et al. Start-up of reactors for anoxic ammonium oxidation: experiences from the first full-scale anammox reactor in Rotterdam. Water Res. 41, 4149-4163 (2007)

6. Chen, W. et al. A novel anammox reactor with a nitrogen gas circulation: performance, granule size, activity, and microbial community. Environ. Sci. Pollut. Res. 27, 18661-18671 (2020).

7. Dapena-Mora, A., Campos, J. L., Mosquera-Corral, A., Jetten, M. S. M. \& Méndez, R. Stability of the ANAMMOX process in a gas-lift reactor and a SBR. J. Biotechnol. 110, 159-170 (2004).

8. Jin, R. C. et al. Performance comparison of two anammox reactors: SBR and UBF. Chem. Eng. J. 138, 224-230 (2008).

9. Chong-jian, T., Ping, Z., Qaisar, M. \& Jian-wei, C. Effect of substrate concentration on stability of anammox biofilm reactors. J. Cent. South Univ. Technol. 4, 1129-1132 (2010).

10. Ni, S. Q. \& Zhang, J. Anaerobic ammonium oxidation: From laboratory to full-scale application. Biomed. Res. Int. 2013, 469360 (2013).

11. Ibrahim, M., Yusof, N., Mohd Yusoff, M. Z. \& Hassan, M. A. Enrichment of anaerobic ammonium oxidation (anammox) bacteria for short start-up of the anammox process: a review. Desalin. Water Treat. 57, 13958-13978 (2016).

12. Wang, Y. et al. Autoclaved sludge as the ideal seed to culture anammox bacteria: reactor performance and microbial community diversity. Bioresour. Technol. 244, 391-399 (2017).

13. Yin, X., Qiao, S., Zhou, J. \& Tang, X. Fast start-up of the anammox process with addition of reduced graphene oxides. Chem. Eng. J. 283, 160-166 (2016).

14. Wang, T., Wang, X., Yuan, L., Luo, Z. \& Kwame Indira, H. Start-up and operational performance of Anammox process in an anaerobic baffled biofilm reactor (ABBR) at a moderate temperature. Bioresour. Technol. 279, 1-9 (2019).

15. Keren, R. et al. Increased replication of dissimilatory nitrate-reducing bacteria leads to decreased anammox bioreactor performance. Microbiome 8, 1-21 (2020).

16. Castro-Barros, C. M., Jia, M., van Loosdrecht, M. C. M., Volcke, E. I. P. \& Winkler, M. K. H. Evaluating the potential for dissimilatory nitrate reduction by anammox bacteria for municipal wastewater treatment. Bioresour. Technol. 233, 363-372 (2017).

17. Han, X., Peng, S., Zhang, L., Lu, P. \& Zhang, D. The co-occurrence of DNRA and anammox during the anaerobic degradation of benzene under denitrification. Chemosphere 247, 125968 (2020).

18. Nie, W. B. et al. Operation strategies of n-DAMO and anammox process based on microbial interactions for high rate nitrogen removal from landfill leachate. Environ. Int. 139, 105596 (2020).

19. Mueller, N. C. et al. Application of nano-scale zero valent iron (NZVI) for groundwater remediation in Europe. Environ. Sci. Pollut. Res. 19, 550-558 (2012).

20. Zhou, Z., Dai, C., Zhou, X., Zhao, J. \& Zhang, Y. The removal of antimony by novel NZVI-zeolite: the role of iron transformation. Water Air Soil Pollut. 226, 2293 (2015).

21. $\mathrm{Xu}, \mathrm{J}$. J. et al. Short-term effects of nano-scale zero-valent iron (nZVI) and hydraulic shock during high-rate anammox wastewater treatment. J. Environ. Manag. 215, 248-257 (2018)

22. Zhang, Z. Z. et al. Unraveling the impact of nano-scale zero-valent iron on the nitrogen removal performance and microbial community of anammox sludge. Bioresour. Technol. 243, 883-892 (2017).

23. Ren, L., Ni, S., Liu, C. \& Liang, S. Effect of zero-valent iron on the start-up performance of anaerobic ammonium oxidation (anammox) process. Environ. Sci. Pollut. Res. Int. 22, 2925-2934 (2015).

24. Richard, L. M. Biological effects of magnetic fields: studies with microorganisms. Can. J. Microbiol. 25, 1145-1151 (1979).

25. Hou, L., Liu, Y., Fan, S. \& Li, J. Magnetic field enhanced denitrification efficiency of immobilized bacterial particles. Water Sci. Technol. 81, 622-629 (2020).

26. Geng, S., Fu, W., Wang, J. \& Zheng, S. Treatment efficiency and microbial community diversity in a magnetic field enhanced sequencing batch reactor (SBR). Environ. Sci. 38, 4715-4724 (2017).

27. Liu, S., Yang, F., Meng, F., Chen, H. \& Gong, Z. Enhanced anammox consortium activity for nitrogen removal: impacts of static magnetic field. J. Biotechnol. 138, 96-102 (2008).

28. Wang, Z. et al. Weak magnetic field: a powerful strategy to enhance partial nitrification. Water Res. 120, 190-198 (2017).
29. Geng, S. et al. Effects of an external magnetic field on microbial functional genes and metabolism of activated sludge based on metagenomic sequencing. Sci. Rep. 10, 1-10 (2020).

30. $\mathrm{Ni}, \mathrm{S}$. Q. et al. Interaction of anammox bacteria and inactive methanogenic granules under high nitrogen selective pressure. Bioresour. Technol. 101, 6910-6915 (2010).

31. Li, W., Zhuang, J., Zhou, Y., Meng, F. \& Kang, D. Metagenomics reveals microbial community differences lead to differential nitrate production in anammox reactors with differing nitrogen loading rates. Water Res. 169, 115279 (2020).

32. Blackburne, R., Yuan, Z. \& Keller, J. Partial nitrification to nitrite using low dissolved oxygen concentration as the main selection factor. Biodegradation 19, 303-312 (2008).

33. Bae, H., Chung, Y. \& Jung, J. Microbial community structure and occurrence of diverse autotrophic ammonium oxidizing microorganisms in the anammox process. Water Sci. Technol. 61, 2723-2732 (2010).

34. Park, H., Wells, G. F., Bae, H., Criddle, C. S. \& Francis, C. A. Occurrence of ammoniaoxidizing archaea in wastewater treatment plant bioreactors. Appl. Environ. Microbiol. 72, 5643-5647 (2006).

35. Park, H. \& Noguera, D. R. Evaluating the effect of dissolved oxygen on ammoniaoxidizing bacterial communities in activated sludge. Water Res. 38, 3275-3286 (2004).

36. Ren, L.-F. et al. Enhancement of anammox performance in a novel non-woven fabric membrane bioreactor (nMBR). RSC Adv. 5, 86875-86884 (2015).

37. Kong, X. et al. Inhibiting excessive acidification using zero-valent iron in anaerobic digestion of food waste at high organic load rates. Bioresour. Technol. 211, 65-71 (2016).

38. Lavania, A. \& Bose, P. Effect of metallic iron concentration on end-product distribution during metallic iron-assisted autotrophic denitrificatio. J. Environ. Eng. 132, 994-1000 (2006).

39. Wu, D., Zheng, S., Ding, A., Sun, G. \& Yang, M. Performance of a zero valent ironbased anaerobic system in swine wastewater treatment. J. Hazard. Mater. 286, 1-6 (2015).

40. You, G. et al. The use of zero-valent iron (ZVI)-microbe technology for wastewater treatment with special attention to the factors influencing performance: a critical review. Crit. Rev. Environ. Sci. Technol. 47, 877-907 (2017).

41. Guo, B. et al. Transformation of the zero transformation of the zero valent iron dosage effect on anammox after long-term culture: from inhibition to promotion. Process Biochem. 78, 132-139 (2019).

42. Xie, Y. \& Cwiertny, D. M. Use of dithionite to extend the reactive lifetime of nanoscale zero-valent iron treatment systems. Environ. Sci. Technol. 44, 8649-8655 (2010).

43. Yang, $\mathrm{H}$. et al. Construction of autotrophic nitrogen removal system based on zero-valent iron (ZVI): performance and mechanism. Water Sci. Technol. 82, 2990-3002 (2020)

44. van Niftrik, L. et al. Combined structural and chemical analysis of the anammoxosome: a membrane-bounded intracytoplasmic compartment in anammox bacteria. J. Struct. Biol. 161, 401-410 (2008).

45. Erdim, E., Yücesoy Özkan, Z., Kurt, H. \& Alpaslan Kocamemi, B. Overcoming challenges in mainstream Anammox applications: utilization of nano-scale zero valent iron (nZVI). Sci. Total Environ. 651, 3023-3033 (2019).

46. Zhang, Z., Hu, H., Xu, J., Shi, Z. \& Deng, R. Effects of inorganic phosphate on a high-rate anammox system: performance and microbial community. Ecol. Eng. 101, 201-210 (2017).

47. Filipič, J., Kraigher, B., Tepuš, B., Kokol, V. \& Mandic-Mulec, I. Effects of low-density static magnetic fields on the growth and activities of wastewater bacteria Escherichia coli and Pseudomonas putida. Bioresour. Technol. 120, 225-232 (2012).

48. Schloss, P. D., Gevers, D. \& Westcott, S. L. Reducing the effects of PCR amplification and sequencing artifacts on 16s rRNA-based studies. PLOS ONE 6, 27310 (2011).

49. Guo, Y. et al. A metabolomic view of how low nitrogen strength favors anammox biomass yield and nitrogen removal capability. Water Res. 143, 387-398 (2018).

50. Sun, N., Ge, C., Ahmad, H. A., Gao, B. \& Ni, S. Q. Realization of microbial community stratification for single-stage nitrogen removal in a sequencing batch biofilter granular reactor. Bioresour. Technol. 241, 681-691 (2017).

51. Zhang, L., Lv, W., Li, S., Geng, Z. \& Yao, H. Nitrogen removal characteristics and comparison of the microbial community structure in different anaerobic ammonia oxidation reactors. Water 11, 230 (2019).

52. Kindaichi, T., Yuri, S., Ozaki, N. \& Ohashi, A. Ecophysiological role and function of uncultured Chloroflexi in an anammox reactor. Water Sci. Technol. 66, 2556-2561 (2012).

53. Cao, S. et al. Integrated anaerobic ammonium oxidization with partial denitrification process for advanced nitrogen removal from high-strength wastewater. Bioresour. Technol. 221, 37-46 (2016a).

54. Chu, Z. et al. Microbial characterization of aggregates within a one-stage nitritation-anammox system using high-throughput amplicon sequencing. Chem. Eng. J. 262, 41-48 (2015). 
55. Yang, Y. et al. Complex microbial nitrogen-cycling networks in three distinct anammox-inoculated wastewater treatment systems. Water Res. 168, 115142 (2019).

56. Du, R. et al. Performance and microbial community analysis of a novel DEAMOX based on partial-denitrification and anammox treating ammonia and nitrate wastewaters. Water Res. 108, 46-56 (2017).

57. Kindaichi, T. et al. In situ activity and spatial organization of anaerobic ammonium-oxidizing (anammox) bacteria in biofilms. Appl. Environ. Microbiol. 73, 4931-4939 (2007).

58. Cheng, Y. F. et al. Effects of $\mathrm{ZnO}$ nanoparticles on high-rate denitrifying granular sludge and the role of phosphate in toxicity attenuation. Environ. Pollut. 251, 166-174 (2019).

59. Zhang, Z. et al. Short-term impacts of $\mathrm{Cu}, \mathrm{CuO}, \mathrm{ZnO}$ and $\mathrm{Ag}$ nanoparticles (NPs) on anammox sludge: CuNPs make a difference. Bioresour. Technol. 235, 281-291 (2017).

60. Van Den Berg, E. M., Van Dongen, U., Abbas, B. \& Van Loosdrecht, M. C. Enrichment of DNRA bacteria in a continuous culture. ISME J. 9, 2153-2161 (2015).

61. van den Berg, E. M., Rombouts, J. L., Kuenen, J. G., Kleerebezem, R. \& van Loosdrecht, M. C. M. Role of nitrite in the competition between denitrification and DNRA in a chemostat enrichment culture. AMB Express 7, 91 (2017).

62. Fernandes et al. Effect of temperature on microbial diversity and nitrogen removal performance of an anammox reactor treating anaerobically pretreated municipal wastewater. Bioresour. Technol. 258, 208-219 (2018).

63. Roland, F. A. E. et al. Denitrification, anaerobic ammonium oxidation, and dissimilatory nitrate reduction to ammonium in an East African Great Lake (Lake Kivu). Limnol. Oceanogr. 63, 687-701 (2017).

64. Li, W. et al. Enrichment of denitratating bacteria from a methylotrophic denitrifying culture. Appl. Microbiol. Biotechnol. 100, 10203-10213 (2016).

65. Mao, Y., Xia, Y. \& Zhang, T. Characterization of Thauera-dominated hydrogenoxidizing autotrophic denitrifying microbial communities by using highthroughput sequencing. Bioresour. Technol. 128, 703-710 (2013).

66. Cao, S., Du, R., Li, B., Ren, N. \& Peng, Y. High-throughput profiling of microbial community structures in an ANAMMOX-UASB reactor treating high-strength wastewater. Appl. Microbiol. Biotechnol. 100, 6457-6467 (2016b).

67. Du, R. et al. Synergy of partial-denitrification and anammox in continuously fed upflow sludge blanket reactor for simultaneous nitrate and ammonia removal at room temperature. Bioresour. Technol. 274, 386-394 (2019).

68. Du, R., Cao, S., Wang, S., Niu, M. \& Peng, Y. Performance of partial denitrification (PD)-ANAMMOX process in simultaneously treating nitrate and low $\mathrm{C} / \mathrm{N}$ domestic wastewater at low temperature. Bioresour. Technol. 219, 420-429 (2016).

69. Jia, S., Han, H., Zhuang, H. \& Hou, B. The pollutants removal and bacterial community dynamics relationship within a full-scale British Gas/Lurgi coal gasification wastewater treatment using a novel system. Bioresour. Technol. 200, 103-110 (2015).

70. Li, H., Chi, Z. \& Yan, B. Successful start-up of the anammox process in constructed wetland microcosms: influence of the electron acceptors on performance, microbial community, and functional genes. Environ. Sci. Pollut. Res. 26, 5202-5209 (2019).

71. Ren, Y. et al. High-rate nitrogen removal and microbial community of an up-flow anammox reactor with ceramics as biomass carrier. Chemosphere 113, 125-131 (2014).

72. Li, Z., Xu, X., Shao, B., Zhang, S. \& Yang, F. Anammox granules formation and performance in a submerged anaerobic membrane bioreactor. Chem. Eng. J. 254, 9-16 (2014).

73. APHA, American Public Health Association. Standard Methods for the Examination of Water and Wastewater, 19th, New York (1995).

74. Kong, Q., Wang, Z. B., Shu, L. \& Miao, M. S. Characterization of the extracellular polymeric substances and microbial community of aerobic granulation sludge exposed to cefalexin. Int. Biodeterior. Biodegrad. 102, 375-382 (2015).
75. Langille, M. G. I. et al. Predictive functional profiling of microbial communities using 16S rRNA marker gene sequences. Nat. Biotechnol. 31, 814-821 (2013).

\section{ACKNOWLEDGEMENTS}

The authors thank the support from the National Natural Science Foundation of China (21777086 and 22076100), Taishan Scholar Youth Expert Program of Shandong Province (tsqn201909005), Key Research \& Developmental Program of Shandong Province (2019JZZY020308), Young Scholars Program of Shandong University (2016WLH16 and 2020QNQT012), Shandong Provincial Key Laboratory of Water and Soil Conservation and Environmental Protection (STKF201914), Jinan Science and Technology Research Leader Studio Project (2020GXRC054), Science and Technology Development Program of Suzhou (SS202017) and Qingdao Science and Technology Huimin Demonstration Guide Project (20-3-4-4-nsh).

\section{AUTHOR CONTRIBUTIONS}

Hafiz Adeel Ahmad wrote, revised, and edited the paper, Beibei Guo performed the research, formal, and microbial analysis. Hafiz Adeel Ahmad and Beibei Guo shared their first authorship. Shou-Qing Ni conceptualization, funding acquisition, resources, supervision, review, and editing. Yiyi Zhao help to draw the figures and revise the research paper. Xuming Zhuang, Shakeel Ahmad, Jiegao Zhu, Yuliang Dong, and Taeho Lee review and editing.

\section{COMPETING INTERESTS}

The authors declare no competing interests.

\section{ADDITIONAL INFORMATION}

Supplementary information The online version contains supplementary material available at https://doi.org/10.1038/s41545-021-00122-5.

Correspondence and requests for materials should be addressed to Y.D. or S.-Q.N.

Reprints and permission information is available at http://www.nature.com/ reprints

Publisher's note Springer Nature remains neutral with regard to jurisdictional claims in published maps and institutional affiliations.

ppen Access This article is licensed under a Creative Commons Attribution 4.0 International License, which permits use, sharing, adaptation, distribution and reproduction in any medium or format, as long as you give appropriate credit to the original author(s) and the source, provide a link to the Creative Commons license, and indicate if changes were made. The images or other third party material in this article are included in the article's Creative Commons license, unless indicated otherwise in a credit line to the material. If material is not included in the article's Creative Commons license and your intended use is not permitted by statutory regulation or exceeds the permitted use, you will need to obtain permission directly from the copyright holder. To view a copy of this license, visit http://creativecommons. org/licenses/by/4.0/.

(c) The Author(s) 2021 